九州大学学術情報リポジトリ

Kyushu University Institutional Repository

\title{
Effects of EDTA Addition on Cu Fractions in Soil to Enhance Cu Absorption by Maize
}

Saeki, Kazutoshi

Inoue, Hiromichi

National Institute of Fruit Science

https://doi.org/10.5109/4615

出版情報：九州大学大学院農学研究院紀要. 50 (1)，pp.1-9，2005-02-01. Faculty of Agriculture， Kyushu University

バージョン :

権利関係 : 


\title{
Effects of EDTA Addition on Cu Fractions in Soil to Enhance Cu Absorption by Maize
}

\author{
Kazutoshi SAEKI* and Hiromichi INOUE'
}

\author{
Biotron Institute, Kyushu University, Hakozaki, 6-10-1, Fukuoka 812-8581, Japan \\ (Received September 1, 2004 and accepted November 11, 2004)
}

\begin{abstract}
The effect of EDTA addition on copper (Cu) fractions in soils and soil solutions were investigated in phytoextraction of $\mathrm{Cu}$ polluted soil (about $290 \mathrm{mg} \mathrm{Cu} \mathrm{kg}^{-1}$ ) by maize (Zea mays L.). $\mathrm{Cu}$ accumulation in the shoots was accelerated by the EDTA addition to the soil. In the non-EDTA added soil, the exchangeable $\mathrm{Cu}$ fraction was $0.3 \%$ of the total $\mathrm{Cu}$ and the organically adsorbed $\mathrm{Cu}$ fraction was dominant (43.4\%). The exchangeable fraction increased by the EDTA addition was $2.4 \%$ of the total $\mathrm{Cu}$, indicating the increase in the plant useful $\mathrm{Cu}$ portion in the soil. The total $\mathrm{Cu}$ concentrations in the soil solutions were also elevated by the EDTA addition. The increments in the EDTA added soil solutions were attributed to the increase in the EDTA-Cu. Consequently, the EDTA addition would increase the amount of EDTA-Cu in the soil solutions, followed by an acceleration of the $\mathrm{Cu}$ accumulation in the maize shoot.
\end{abstract}

\section{INTRODUCTION}

More than 150 metal mines are distributed all over Japan (Kitagishi and Yamane, 1981). About half of them have ore containing copper (Cu). Most of the mines are located in the mountain areas (Taniyama, 1991). Copper contamination has spread through the irrigation system to the down-stream paddy fields that have developed in the low land areas. Although $\mathrm{Cu}$ is an essential element for plants, excessive uptake of the element could cause direct toxicity to plants and environmental risk due to biomagnification in food webs (Kabata-Pendias, 2001). The remediation of $\mathrm{Cu}$ polluted agricultural soils has been an important need in last decades in Japan.

Conventional techniques for remediation of heavy metal polluted soils are time consuming, expensive, and labor-cost. Phytoextraction is likely to be a novel method that could clean-up metals from soils using conventional crop cultivation. A plant's ability for phytoextraction may be evaluated by the biomass production as well as by the heavy metal absorption capacity. Indian mustard (Brassica juncea) has been frequently studied for heavy metal phytoextraction due to its high accumulation capabilities (Ebbs and Kochian, 1998; Quartacci et al., 2001). However, the biomass production of Indian mustard is extremely low, about $0.5 \mathrm{~g}$ per plant in dry weight (Quartacci et al., 2001). Therefore, maize (Zea mays L.) is often used as an experimental species for phytoextraction because of the high biomass production and its comparatively strong heavy metals-resistance (Huang et al., 1997; Wu et al., 1999; Lombi et al., 2001; Ali et al., 2002; Wenger et al., 2002).

1 National Institute of Fruit Tree Science, Fujimoto 2-1, Tsukuba 305-8605, Japan

* Corresponding author (E-mail: ksaeki@agr.kyushu-u.ac.jp) 
The addition of chemicals, such as a chelating agents, to soils has been used as a method to enhance the extraction of heavy metals by plants. For example, Huang et al. (1997) found that the lead absorption by peas (Pisum sativum L.) increased with the addition of EDTA. Similarly, the Pb accumulation increased in Indian mustard and in wheat (Triticum aestivum L.) with the addition of EDTA as reported by Blaylock et al. (1997) and Begonia et al. (2002), respectively. EDTA addition to metal-polluted soils elevated $\mathrm{Zn}$ accumulation in Indian mustard, but had no effect on oat (Avena sativa L.) and barley (Hordeum vulgare L.) (Ebbs and Kochian, 1998). Translocations of $\mathrm{Pb}$ and $\mathrm{Cd}$ from the root to shoot of radish (Raphanus sativus L.) were enhanced by the addition of citric acid, resulting in reduction of soil toxicity to plants (Chen et al., 2003). Increases of Se absorption in barley and wheat were also observed with the additions of organic acids such as ascorbic acid to soils (Blaylock and James, 1994). These observations showed the efficiency of application of some cheleting agents for phytoextraction of metal polluted soils.

An important secondary effect in situ of addition of cheleting agents to metal polluted soil may be the leaching of soluble metals into the ground water (Grcman et al., 2001). Good estimation of the amount of metals available to plants induced by application of cheleting agents to soils is essential in order to efficiently raise the heavy metals absorption by the plants along with a control of leaching to ground water. Sequential chemical extraction methods are often used to determine the fractions of heavy metals in soils and sediments (McLaren and Crawford, 1973; Tessier et al., 1979; Sadamoto et al., 1994; Saeki et al., 1993a, b). Among these fractions, metals in soil solution are very important for the plant-soil relationships, because almost all terrestrial plants absorb most of their essential elements through soil solution; in other words, only heavy metals dissolved in the soil solution can be absorbed by plants. Therefore, it is also essential for phytoextraction to analyze the amount and the forms of heavy metals present in soil solutions. Several studies reported that heavy metal concentrations in soil solutions are increased by application of cheleting agents (Huang et al., 1997; Jiang et al., 2003; Wu et al., 1999, 2003). No research has been carried out to determine the amount of chelated metals in soil solutions after application of cheleting agents to soils, such as EDTA-Cu, in relation to phytoextraction.

In a previous study, we compared the efficiency of the EDTA application for $\mathrm{Cu}$ removal from contaminated soils by Indian mustard and by maize (Inoue et al., 2003). The purpose of the present study is to investigate the effects of the EDTA addition on the $\mathrm{Cu}$ forms in soils and soil solution for phytoextraction by maize.

\section{MATERIALS AND METHODS}

\section{Soils and plant cultivation}

The present study used a volcanic ash soil (Andosol) collected from a field at the National Agricultural Reseach Center for the Kyushu Okinawa Region in Nishigoushi, Kumamoto. The basic properties of the soil were $\mathrm{pH}\left(\mathrm{H}_{2} \mathrm{O}\right) 5.6 ; 23.3 \%$ organic matter; $31.2 \mathrm{cmol} \mathrm{kg}^{-1} \mathrm{CEC}$; and $42.2 \mathrm{mg} \mathrm{g}^{-1}$ total $\mathrm{Cu}$. Andosol was not fertilized because of the continuous application of manure before the cultivation. Soils were mixed with anhydrous copper (II) sulfate powder to $250 \mathrm{mg}$ Cu per $\mathrm{kg}$ soil. The Cu spiked soil was mixed 
with water to $50 \%$ of the field water capacity and incubated for 1 week at room temperature (about $293 \mathrm{~K}$ ), then used for maize cultivation.

Maize (Zea mays L. cv. pioneer 33G26) was grown in a $350 \mathrm{~mL}$ size pot for 3 weeks inside a phytotron (at room temperature of $298 \mathrm{~K}$ and $70 \%$ humidity). Distilled water was daily added to the soils to maintain field water capacity $\left(0.60 \mathrm{~m}^{3} \mathrm{~m}^{-3}\right)$ during the cultivation.

Shoots and roots were sampled 3 weeks after the sowing; dried at $343 \mathrm{~K}$ and milled. The milled samples were ashed at $773 \mathrm{~K}$, and then dissolved in dilute $\mathrm{HCl}$ and $\mathrm{HNO}_{\text {: }}$ solution. The copper concentration of the digested solutions was measured by atomic absorption spectrometry (AAS) (Shimazu Co., Ltd., AA-670).

\section{EDTA addition}

Ten mL of a EDTA2Na solution of $0,0.1,1,10$, and $100 \mathrm{mmol} \mathrm{L}^{-1}(\mathrm{mM})$ were added by syringe to the soil surface one week after sowing. The amount of EDTA2Na addition corresponds to $3.33 \mathrm{mmol} \mathrm{kg}^{-1}$ soil $\left(1.12 \mathrm{~g} \mathrm{~kg}^{-1}\right.$ soil) in the EDTA $100 \mathrm{mM}$ treatment.

\section{Sequential chemical extraction}

After plant cultivation, the $\mathrm{Cu}$ fractions of the soils were analyzed by a method modified by Sadamoto et al. (1994). Three $g$ of soil was shaken with $30 \mathrm{~mL}$ of $0.05 \mathrm{~mol} \mathrm{~L}^{-1}$ potassium nitrate for $24 \mathrm{~h}$ in a $50 \mathrm{~mL}$ tube. The supernatant taken from the tube after centrifuging and filtering through $0.22 \mu \mathrm{m}$ pore size filter was used for the analysis (ion-exchangeable form ( $\mathrm{EX}$ fraction)). The residue from the above extraction was shaken for $24 \mathrm{~h}$ with $30 \mathrm{~mL}$ of $25 \mathrm{~g} \mathrm{~L}^{-1}$ acetic acid. The supernatant obtained by centrifuging and filtering was used for the analysis (form specifically adsorbed on clay minerals (AC fraction)). The residue was digested with $30 \mathrm{~mL}$ of $6 \%$ hydrogen peroxide, dried, then extracted with $30 \mathrm{~mL}$ of $25 \mathrm{~g} \mathrm{~L}^{-1}$ acetic acid, with shaking for $24 \mathrm{~h}$. The supernatant obtained by centrifuging and filtrating was used for the analysis (form specifically adsorbed in organic matter (ORG fraction)). One gram of the residue was added to a $30 \mathrm{~mL}$ mixture of $0.1 \mathrm{~mol} \mathrm{~L}^{-1}$ oxalic acid and $0.175 \mathrm{~mol} \mathrm{~L}^{-1}$ ammonium oxalate and with $1 \mathrm{~g}$ ascorbic acid powder, then shaken for $1 \mathrm{~h}$ in a boiling water bath. The supernatant obtained by centrifuging and filtrating was used for the analysis (form occluded in oxides (OX fraction)). The final residue was digested by perchloric acid and the liquid phase obtained by filtrating was used for analysis (residue (LA fraction)). Copper in the solutions from each fraction was determined using AAS.

\section{Analysis of EDTA-Cu in soil solution}

Samples of the soil solutions were obtained from a water-saturated extract prepared by the modified method of Rhoades (1982) (Saeki et al., 2002). The water-soil mixture was centrifuged at $3500 \times g$, and then the extract was filtrated through a $0.22 \mu \mathrm{m}$ pore size filter. The solutions were then measured for total $\mathrm{Cu}$ by graphite furnace AAS (Nippon Jarrell-Ash Co. Ltd., SOLAAR AA).

The soil solution was passed through an anion exchange type column (TOA, PCI-201S, $4.6 \times 100 \mathrm{~mm}$ ) using an HPLC (TOA, ICA-5220). The operational condition for the HPLC is listed as follows; Eluent: a mixed solution of $3 \mathrm{mmol} \mathrm{L}^{-1}$ phthalic acid, $2.74 \mathrm{mmol} \mathrm{L}^{-1}$ tris (hydroxymetyl) aminomethane and $200 \mathrm{mmol} \mathrm{L}^{-1}$ boric acid, Flow rate: 
$0.9 \mathrm{~mL} \mathrm{~min}^{-1}$, Injected sample volume: $10 \mu \mathrm{L}$. The eluted liquid after the column passage was divided into $0.9 \mathrm{~mL}$ using a fraction collector. The copper in each fraction of the elutes was determined by graphite furnace AAS.

\section{Statistical analysis}

Each experiment was performed in triplicate. The variance for each of the results was analyzed and the differences between the averaged values was tested using Tukey's method.

\section{RESULTS AND DISCUSSION}

\section{Cu accumulation by maize}

Table 1 shows that $\mathrm{Cu}$ concentration in maize shoots with the 10 and the $100 \mathrm{mM}$ EDTA treatments were higher than the $0 \mathrm{mM}$ EDTA treatment but without any significant difference. The shoot dry weight in the 10 and the $100 \mathrm{mM}$ EDTA treatments were lower than the $0 \mathrm{mM}$ EDTA treatment. Cu accumulation in maize shoots in the $100 \mathrm{mM}$ EDTA treatment was 3.7 times greater than in the 0 mM EDTA treatment $(p<0.01)$. It confirmed that the addition of EDTA has effectively enhanced $\mathrm{Cu}$ accumulation in the maize shoot. Two possible mechanisms are assumed to cause the increase in the $\mathrm{Cu}$ accumulation in the shoot by the EDTA addition. One is that the $\mathrm{Cu}$ accumulated by the roots combines with EDTA, then transported to the shoot as the form of EDTA-Cu. Another is that $\mathrm{Cu}$ adsorbed on the soil particles are desorbed by EDTA, then converted to EDTA-Cu in the soil solution, which could be easily absorbed by the maize. The latter can be confirmed by an investigation of the $\mathrm{Cu}$ forms in the soil and the existence of EDTA-Cu in the soil solution.

Table 1. Copper concentration, dry weight of shoot, and $\mathrm{Cu}$ accumulation of Zea mays.

\begin{tabular}{|c|c|c|c|c|c|c|}
\hline $\begin{array}{l}\text { EDTA treatment } \\
\left(\text { immol L }{ }^{-1}\right)\end{array}$ & \multicolumn{2}{|c|}{$\begin{array}{c}\text { Cu conc. } \\
\left(\mu \mathrm{g} \mathrm{g}^{-1}\right)\end{array}$} & \multicolumn{2}{|c|}{$\begin{array}{l}\text { Dry weight } \\
\left(\mathrm{g} \text { plant }^{-1}\right)\end{array}$} & \multicolumn{2}{|c|}{$\begin{array}{l}\text { Cu accumulation } \\
\left(\mu \text { g plant }^{-1}\right)\end{array}$} \\
\hline & \multicolumn{2}{|c|}{$\operatorname{avg} \pm \mathrm{SE}$} & \multicolumn{2}{|c|}{$\operatorname{avg} \pm S E$} & \multicolumn{2}{|c|}{$\operatorname{avg} \pm S E$} \\
\hline 0 & $8.6 \pm$ & $1.0 \mathrm{NS}$ & $0.47 \pm$ & $0.04 \mathrm{NS}$ & $3.9 \pm$ & $0.36 \mathrm{a}$ \\
\hline 0.1 & $9.3 \pm$ & 0.9 & $0.53 \pm$ & 0.04 & $4.9 \pm$ & $0.72 \mathrm{a}$ \\
\hline 1 & $8.8 \pm$ & 0.6 & $0.52 \pm$ & 0.04 & $4.6 \pm$ & $0.63 \mathrm{a}$ \\
\hline 10 & $14.0 \pm$ & 3.1 & $0.39 \pm$ & 0.10 & $4.9 \pm$ & $0.12 \mathrm{a}$ \\
\hline 100 & $71.7 \pm$ & 34.1 & $0.25 \pm$ & 0.06 & $14.4 \pm$ & $3.48 \mathrm{~b}$ \\
\hline
\end{tabular}

NS shows no significant difference.

Different letters show $5 \%$ significant difference.

\section{Fractionation of soil $\mathrm{Cu}$ by sequential chemical extraction}

Copper fractionations in soil after cultivation were done in both the $0 \mathrm{mM}$ and $100 \mathrm{mM}$ EDTA treatments in order to investigate the effect of the EDTA addition to the soils on the $\mathrm{Cu}$ forms (Table 2). The Ex-Cu concentration increased from 0.9 to $7.4 \mathrm{mg} \mathrm{kg}^{-1}$ by the 
Table 2. Copper concentration among different fractions of cultivated $\mathrm{Cu}$ mixed soil.

\begin{tabular}{lrrrr}
\hline & $\left(0 \mathrm{mmol} \mathrm{L}^{-1}\right)$ & & $(100 \mathrm{mmol} \mathrm{L}$ \\
\cline { 2 - 5 } & \multicolumn{2}{c}{$\operatorname{avg} \pm \mathrm{SE}$} & \multicolumn{2}{c}{ avg $\pm \mathrm{SE}$} \\
\hline EX fraction* & $0.9 \pm$ & 0.0 & $7.3 \pm$ & 0.1 \\
AC fraction & $12.1 \pm$ & 0.5 & $11.3 \pm$ & 0.3 \\
ORG fraction & $132.1 \pm$ & 8.9 & $123.9 \pm$ & 6.4 \\
OX fraction & $89.1 \pm$ & 10.7 & $85.7 \pm$ & 3.7 \\
LA fraction & $69.8 \pm$ & 1.5 & $74.9 \pm$ & 1.2 \\
\hline
\end{tabular}

* $5 \%$ significant difference.

$100 \mathrm{mM}$ EDTA treatment. These Ex fractions were only 0.3 and $2.4 \%$ of the total $\mathrm{Cu}$ in the $0 \mathrm{mM}$ and the $100 \mathrm{mM}$ EDTA treatments, respectively. The ORG-Cu fractions decreased from $132 \mathrm{mg} \mathrm{kg}^{-1}$ (43.4\%) to $124 \mathrm{mg} \mathrm{kg}^{-1}$ (40.9\%) due to the EDTA addition. The OX-Cu fractions were also slightly reduced from $89.1 \mathrm{mg} \mathrm{kg}^{-1}$ in the $0 \mathrm{mM}$ treatment to $85.7 \mathrm{mg} \mathrm{kg}^{-1}$ in the $100 \mathrm{mM}$ EDTA treatment. There was no change in the LA fraction. Most of the $\mathrm{Cu}$ portions in the 24 England soils were in the residue fraction (24-77\%), and the exchangeable fraction was less than $0.2 \%$ (only a sample, 2.3\%) (McLaren and Crawford, 1973). Tessier et al. (1979) reported that the residual fraction of $\mathrm{Cu}$ was about $40 \%$ whereas the exchangeable fraction of $\mathrm{Cu}$ was under $1 \%$ in the sediments. Even in polluted soils, the plant-available $\mathrm{Cu}$ fractions (exchangeable) were several \% of the total soil $\mathrm{Cu}$ content (Sadamoto et al., 1994). Because the $\mathrm{Cu}$ polluted soil was artificially made by adding the reagent $\mathrm{CuSO}_{4}$ into the study soils, the proportion of the exchangeable $\mathrm{Cu}$ to the total $\mathrm{Cu}$ content was expected to be higher than in the actual polluted soils. However, the exchangeable fraction in this soil was similar to the reported levels of in situ actually polluted soils. These results indicated that the EDTA addition to the soils could efficiently increase the amount of the plant-available $\mathrm{Cu}$ portion, although being a small proportion of the total soil $\mathrm{Cu}$.

\section{Analysis of $\mathrm{Cu}$ in the soil solutions}

It has been reported that the heavy metal $(\mathrm{Pb}, \mathrm{Cd}$ and $\mathrm{Cu})$ concentrations in the soil solution increased due to EDTA addition to the soils (Huang et al., 1997; Jiang et al., 2003; Wu et al., 1999, 2003). Similar to these reports, Cu concentration in the soil solution rose proportionally with added EDTA to soils (Fig. 1). The copper concentration in the soil solution in the $100 \mathrm{mM}$ treated soil was significantly higher than those in the other soils $(p<0.05)$.

Each chromatograph of $\mathrm{Cu}$ ion and EDTA-Cu was checked using $\mathrm{CuSO}_{4}$ and EDTA2Na solutions (Fig. 2). When injecting only a $2 \mathrm{mmol} \mathrm{L}^{-1} \mathrm{CuSO}_{4}$ solution to the HPLC, most of the $\mathrm{Cu}$ was detected in the $2 \mathrm{~min}$. fraction (meaning that the elute portion was taken from 2 to 3 minutes after passing through the column) with a small peak in the $3 \mathrm{~min}$. fraction. Copper was detected in the 7, 8,9 min. fractions with a maximum peak for the $8 \mathrm{~min}$. fraction in an injection of a $1: 1(\mathrm{v} / \mathrm{v})$ mixture of the $2 \mathrm{mmol} \mathrm{L}^{-1}$ EDTA2Na and the $2 \mathrm{mmol} \mathrm{L}^{-1} \mathrm{CuSO}_{4}$ solutions. Therefore, we assumed that the $\mathrm{Cu}$ peaks observed in the 7 to the $9 \mathrm{~min}$. fractions corresponded to EDTA-Cu. With a 2:1 (v/v) mixture of the 


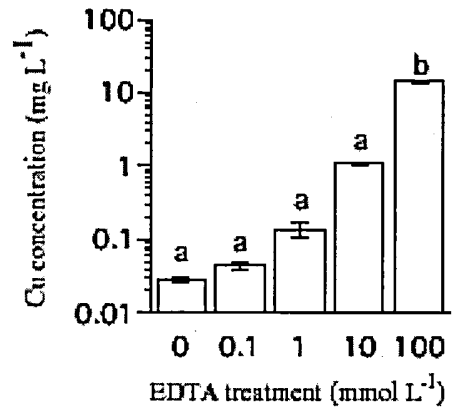

Fig. 1. Copper concentration in soil solution of $\mathrm{Cu}-$ spiked soil. Error bars represent standard error range of the mean, $n=3$. Different letters show $5 \%$ significant difference.

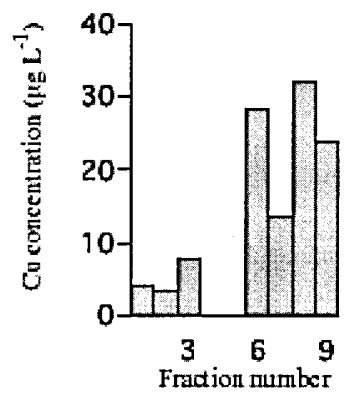

Fig. 3. Copper fractions of the soil solution in the EDTA 100 mrnol L $^{-1}$ treatment soil.

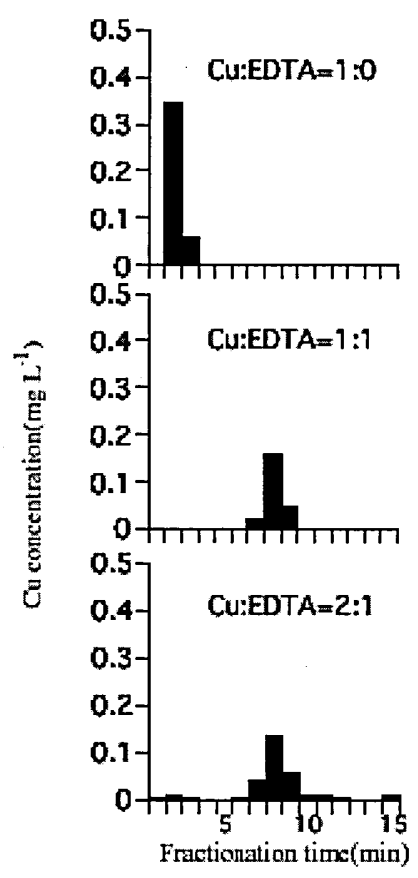

Fig. 2. Copper concentrations of the solution mixed $\mathrm{CuSO}_{4}$ and EDTA2Na fractionated by the anion exchange column.

EDTA2Na and the $\mathrm{CuSO}_{4}$ solutions, $\mathrm{Cu}$ was detected in the 1, 2, and $3 \mathrm{~min}$. fractions and in the $6,7,8$, and $9 \mathrm{~min}$. fractions with largest peaks in the $2 \mathrm{~min}$. fraction and the $8 \mathrm{~min}$. fraction. This result means that the $\mathrm{Cu}$ ion and EDTA-Cu existed together in the mixture though most of the $\mathrm{Cu}$ existed as EDTA-Cu. Probably, the existent ratio of $\mathrm{Cu}$ ion: EDTA-Cu was not 1:1 in the 2:1 mixture of EDTA2Na and $\mathrm{CuSO}_{4}$ solutions. Any $\mathrm{Cu}$ compounds eluted in the $6 \mathrm{~min}$. fraction could not be exactly identified, but one can certainly distinguish this portion from the $\mathrm{Cu}$ ion.

A chromatograph of the soil solution of the $100 \mathrm{mM}$ EDTA treatment is shown in Fig. 3. Copper in the soil solution was divided into the 1 to $3 \mathrm{~min}$. fractions and into the 6 to 9 min. fractions. When interpreting $\mathrm{Cu}$ in the 7 to $9 \mathrm{~min}$. fractions as EDTA-Cu, we calculated that $61.4 \%$ of the total $\mathrm{Cu}$ in the soil solution existed as EDTA-Cu. The $\mathrm{Cu}$ ion was estimated to be only $15.2 \%$ of the total $\mathrm{Cu}$.

Because the $2 \mathrm{~min}$. and the $8 \mathrm{~min}$. fractions had the largest peaks in the 1,2 , and $3 \mathrm{~min}$. and in the $6,7,8$, and 9 min. fractions, respectively, both in Figs. 2 and 3, this study 


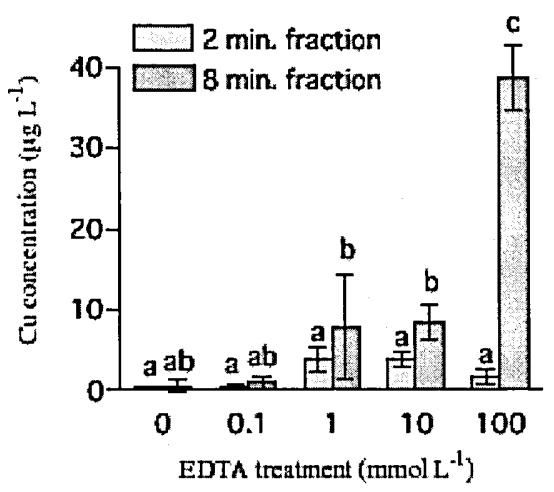

Fig. 4. Copper concentration of soil solution of $\mathrm{Cu}$-mixed soil fractionated by anion exchange column. Error bars: standard error range of the mean, $n=3$. Different letters show $5 \%$ significant difference.

regarded the $2 \mathrm{~min}$. fraction and the $8 \mathrm{~min}$. fraction as representatives of the $\mathrm{Cu}$ ion and EDTA-Cu in the soil solutions, as shown in Fig. 4. The $\mathrm{Cu}$ in the 2 min. fractions did not significantly fluctuate with the concentration of added EDTA, implying that $\mathrm{Cu}$ ion in the soil solution was not drastically increased by the EDTA additions to the soil. In contrast, the $\mathrm{Cu}$ concentration in the $8 \mathrm{~min}$. fraction with the $100 \mathrm{mM}$ EDTA treatment was higher than those in the other treatments $(p<0.05)$. However, this $\mathrm{Cu}$ concentration did not increase in proportion to the added EDTA concentrations.

The $\mathrm{Cu}$ amounts were significantly higher in the $8 \mathrm{~min}$. fractions than that in the 2 min. fractions of the 1,10 and $100 \mathrm{mM}$ EDTA treatments $(p<0.05)$. These results indicated that the EDTA-Cu in the soil solution is drastically increased by the addition of EDTA to the soil, whereas the concentration of $\mathrm{Cu}$ ion is not greatly changed by this addition. Consequently, the change in $\mathrm{Cu}$ accumulation in the maize by the EDTA addition to the soil follows the increase in the exchangeable fraction in the soil or especially of the EDTA-Cu in the soil solution.

For the EDTA application to soils, one should pay attention to its direct toxicity to plants and its leaching into the ground water systems. Our previous study showed that the maize shoot, which was in contact with the $100 \mathrm{mmol} \mathrm{L}^{-1}$ EDTA solution at 7 days after sowing died, probably because of salt damage induced by the EDTA addition (Inoue et al. 2003). In this study, the dry weights of the maize shoot after the $100 \mathrm{mM}$ EDTA treatment also decreased compared to those in no EDTA treatment without significance. The efficiency of phytoextraction generally deceases with the decrease in the plant biomass due to the toxicity of EDTA or EDTA-metals. The countermeasures against the salt damage may be suggested; lowering the EDTA concentration and the addition at a specific growth stage. The EDTA or EDTA-metals leaching into the groundwater systems should be prevented by controlling the amount of added EDTA to have a balance between the plant available metal amount and the soluble metal amount by EDTA, and monitoring the 
concentrations of heavy metals in the soil solutions. Any studies for both of these problems would require investigating the $\mathrm{Cu}$ speciation in any plant tissues which absorbed the EDTA-Cu from the soil solutions.

\section{ACKNOWLEDGEMENTS}

The authors are grateful to Mr. Teruhito Miyamoto, Kyushu Okinawa agriculture research center for soil sampling. The authors would also like to thank Mr. Hiroki Mori, soil science laboratory, Kyushu University for the $\mathrm{Cu}$ analysis by furnace type atomic absorption spectrometer. This study was supported by grant-in-aid for scientific research of Japan society for the promotion of science (subject No. 14350259).

\section{REFERENCES}

Ali, N. A., M. P. Bernal and M. Ater 2002 Tolerance and bioaccumulation of copper in Phragmites australis and Zea mays. Plant and Soil, 239: 103-111

Begonia, M. F. T., G. B. Begonia, A. Butler, M. Burrell, O. Ighoavodha and B. Crudup 2002 Chelate-assisted phytoextraction of lead from a contaminated soil using wheat (Triticum aestivum L.). Bull. Environ. Contam. Toxicol., 68: 705-711

Blaylock, M. J. and B. R. James 1994 Redox transformations and plant uptake of selenium resulting from root-soil interactions. Plant and Soil., 158: 1-12

Blaylock, M. J., D. E. Salt, S. Dushenkov, O. Zakharova, C. Gussman, Y. Kapulnik, B. D. Ensley and I. Raskin 1997 Enhanced accumulation of $\mathrm{Pb}$ in Indian mustard by soil-applied chelating agents. Environ. Sci. Technol., 31: 860-865

Chen, Y. X., Q. Lin, Y. M. Luo, Y. F. He, S. J. Zhen, Y. L. Yu, G. M. Tian and M. H. Wong 2003 The role of citric acid on the phytoremediation of heavy metal contaminated soil. Chemosphere, 50: 807-811

Ebbs, S. D. and L. V. Kochian 1998 Phytoextraction of zinc by oat (Avena sativa), barley (Hordeum vulgare), and Indian mustard (Brassica juncea). Environ. Sci. Technol., 32: 802-806

Grcman, H., S. Velikonja-Bolta, D. Vodnik, B. Kos and D. Lestan 2001 EDTA enhanced heavy metal phytoextraction: metal accumulation, leaching and toxicity. Plant and Soil, 235: 105-114

Huang, J. W., J. J. Chen, W. R. Berti and S. D. Cunningham 1997 Phytoremediation of lead-contaminated soils: Role of synthetic chelates in lead phytoextraction. Environ. Sci. Technol., 31: 800-805

Inoue, H., K. Saeki and J. Chikushi 2003 Effect of EDTA on phytoremediation of copper-polluted soils. J. Fac. Agr. Kyushu Univ., 47: 243-250

Jiang, X. J., Y. M. Luo, Q. G. Zhao, A. J. M. Baker, P. Christie and M. H. Wong, 2003 Soil Cd availability to Indian mustard and environmental risk following EDTA addition to Cd-contaminated soil. Chemosphere, 50: $813-818$

Kabata-pendias, A. 2001 Trace elements in soils and plants. 3rd edition. CRC Press, Boca Raton (U.S.A.), pp. 115

Kitagishi, K. and I. Yamane 1981 Heavy metal pollution in soil of Japan. Japan Scientific Societies Press, Tokyo, pp. 302

Lombi, E., F. J. Zhao, S. J. Dunham and S. P. McGrath, 2001. Phytoremediation of heavy metal-contaminated soils: natural hyperaccumulation versus chemically enhanced phytoextraction. J. Environ. Qual., 30: 1919-1926

McLaren, R. G. and D. V. Crawford 1973 Studies on soil copper. I. The fractionation of copper in soils. J. Soil Sci., 24: 172-181

Quartacci, M. F., E. Cosi and F. Navari-izzo 2001 Uptake and translocation of cadmium in Brassicaceae. Minerva Biotec, 13: 97-101

Rhoades, J. D. 1982 Soluble salts. In "Methods of Soil Analysis, Part 2. Chemical and Microbiological Properties (2nd Edition)," ed. by A. L. Page et al., American Society of Agronomy Inc., Soil Science Society of America Inc. Publisher, pp. 167-169

Saeki, K., M. Okazaki and M. Kubota 1993a Heavy metal accumulations in a semi-enclosed hypereu- 
trophic system: lake teganuma, Japan. Part 2. heavy metal accumulations in sediments. Water Air Soil Pollut., 69: 79-91

Saeki, K., M. Okazaki and S. Matsumoto. 1993b The chemical phase changes in heavy metals with drying and oxidation of the lake sediments. Wat. Res., 27: 1243-1251

Saeki, K., T. Kunito, H. Oyaizu and S. Matsumoto 2002 Relationships between bacterial tolerance levels and forms of copper and zinc in soils. J. Environ. Qual., 31: 1570-1575

Sadamoto, H., K. Iimura, T. Honna and S. Yamamoto 1994 Examination of fractionation of heavy metals in soils. Jpn. J. soil Sci. Plant Nutr., 65: 645-653 (in Japanese)

Taniyama, T. 1991. Chikyu Kankyo Hozen Gairon. University of Tokyo Press, Tokyo (in Japanese)

Tessier, A., P. G. Campbell and M. Bisson 1979 Sequential extraction procedure for the speciation of particulate trace metals. Anal. Chem., 61: 844-851

Wenger, K, S. K. Gupta, G. Furrer and R. Schulin 2002 Zinc extraction potential of two common crop plants, Nicotiana tabacum and Zea mays. Plant and Soil, 242: 217-225

Wu, J., F. C. Hsu and S. D. Cunningham 1999 Chelate-assisted Pb phytoextraction: Pb availability, uptake, and translocation constrains. Environ. Sci. Technol., 33: 1898-1904

Wu, L. H., Y. M. Luo, P. Christie and M. H. Wong, 2003 Effects of EDTA and low molecular weight organic acids on soil solution properties of a heavy metal polluted soil. Chemosphere, 50: 819-822 